\title{
Naringin supplementation affects performance, carcass traits, meat quality and oxidative stability of finishing pigs
}

\author{
Q. Wang ${ }^{1,2}$, J. Wang ${ }^{1,2}$, R.L. Qi ${ }^{1,2}$, X.Y. Qiu ${ }^{1}$, Q. Sun ${ }^{1} \&$ J.X. Huang ${ }^{1,2 \#}$ \\ ${ }^{1}$ Chongqing Academy of Animal Sciences, Chongqing 402460, China \\ ${ }^{2}$ Key Laboratory of Pig Industry Sciences, Ministry of Agriculture; Chongqing Key Laboratory of Pig Industry Sciences, \\ Chongqing 402460, China
}

(Received 27 June 2019; Accepted 5 January 2020; First published online 16 February 2020)

\author{
Copyright resides with the authors in terms of the Creative Commons Attribution 4.0 South African Licence. \\ See: http://creativecommons.org/licenses/by/4.0/za \\ Condition of use: The user may copy, distribute, transmit and adapt the work, but must recognise the authors and \\ the South African Journal of Animal Science.
}

\begin{abstract}
Naringin is a major flavanone derivate that has many important biological functions in animals. However, its effect on pigs is unknown. The aim of this study was to investigate the effect of naringin supplementation on performance, carcass traits, meat quality and oxidative stability in finishing pigs. Ninetysix pigs, with an average initial body weight of $66.2 \pm 0.63 \mathrm{~kg}$, were randomly divided into four groups. One group was fed a basal diet without supplementation (control), and the three others were fed diets supplemented with $0.5,1.0$ or $1.5 \mathrm{~g}$ naringin $/ \mathrm{kg} \mathrm{DM}$ of feed for 50 days. Each treatment was replicated six times with four pigs per replicate. Feed and water were available ad libitum. The $0.5 \mathrm{~g} / \mathrm{kg}$ naringin treatment group had an improved loin eye muscle area, reduced serum triglycerides and were leaner compared with the other groups. Pigs in the $1.5 \mathrm{~g} / \mathrm{kg}$ naringin treatment had higher $\mathrm{pH}_{45 \mathrm{~min}}$ values and inosine monophosphate concentrations, and lower MyHC IIb mRNA expression in muscle than the other groups. MyHC Ila mRNA expression was significantly up-regulated in all naringin-supplemented diet groups. Naringin significantly increased superoxide dismutase (SOD) activity and total anti-oxidative capacity in meat, as well as SOD and glutathione peroxidase activity in the liver. These results indicate that the dietary addition of naringin at $0.5 \mathrm{~g} / \mathrm{kg}$ improved carcass characteristics, while $1.5 \mathrm{~g} / \mathrm{kg}$ improved the oxidative stability and pork quality in finishing pigs.
\end{abstract}

Keywords: antioxidant capacity; carcass characteristics; naringin-supplemented diets; pork quality

\#Corresponding author: short00@163.com

\section{Introduction}

Flavonoids are natural compounds with various biogenic functions. The most important flavanone derivates, including naringin, hesperidin, catechin, quercetin, apigenin and kaempferol, have been shown to have anti-oxidative, anti-inflammatory, anti-hypolipidemic and anti-carcinogenic effects (Ahmad et al., 2015; Alam et al., 2014; Boots et al., 2008; Burkina et al., 2016; Kamboh \& Zhu, 2013; Zaidun et al., 2018). In recent years, there has been broad interest in the use of flavonoids in livestock, since they can retard lipid oxidation and improve meat quality parameters without leaving residue in the product (Jiang \& Xiong, 2016; Salami et al., 2016).

Naringin is a major flavanone glycoside obtained from citrus fruits. It was first isolated in 1928 by Asahina and Inubuse (Asahina \& Inubuse, 1928; Bharti et al., 2014). Naringin is composed of naringenin, an aglycone and neohesperidose attached to the hydroxyl group at C-7, and possesses strong antiinflammatory and antioxidant activities (Jiao et al., 2015). Several studies have suggested that naringin supplementation is beneficial for the treatment of obesity, diabetes, hypertension and metabolic syndrome in humans (Viswanatha et al., 2017; Zaidun et al., 2018). Due to the beneficial effect of naringin on animal health, the European Food Safety Authority authorized its use as a feed additive for animals in 2011 (EFSA, 2011). Recent studies in broiler chickens, lambs and rabbits demonstrated that naringin supplementation greatly improved the oxidative stability of meat, but did not affect growth or meat quality characteristics (Bodas et al., 2012; Goliomytis et al., 2015; Jeon et al., 2004). 
Dietary antioxidants have many biogenic effects in pigs. For example, González and Tejeda (2007) reported that dietary supplementation with RRR-a-tocopheryl-acetate had a significant influence on lipid oxidation in Iberian pig meat. The incorporation of an antioxidant blend into the diet of weaned piglets, significantly elevated total anti-oxidative capacity (T-AOC), activity of superoxide dismutase (SOD) and glutathione peroxidase (GPx), and reduced malondialdehyde (MDA) content in the jejunum and colon tissues (Xu et al., 2014). Additionally, hesperidin had a positive effect on performance and antioxidant function in the weaned piglets (Liu et al., 2009), and naringin improved growth performance and nutrient digestibility in postweaning piglets (Goodarzi Boroojeni et al., 2018). Naringin is a flavanone derivate that is beneficial, however its effects on finishing pigs are unknown. The objective of the current study was to explore the effects of different levels of naringin on performance, carcass traits, meat quality and oxidative stability in finishing pigs, in order to elucidate the functional effects and optimal use of naringin in pig diets.

\section{Materials and methods}

All research involving animals was performed according to the Regulations for the Administration of Affairs Concerning Experimental Animals. The Institute Ethics Committee of the Chongqing Academy of Animal Science approved the relevant ethical issues in this study (permit number: xky-20180312).

Naringin (purity $\geq 95 \%$ ) was obtained from Xi'an Haoxuan Biotechnology Company (Xi'an, China). A total of 96 Yorkshire $\times$ Rongchang pigs, with an initial body weight of $66.2 \pm 0.63 \mathrm{~kg}$, were randomly allocated to four treatments. Each treatment consisted of six replicates with four pigs per replicate (half males and half females). The control group (N0) was fed a basal diet, and the three treated groups (N1, N2, N3) were fed the control diet supplemented with $0.5,1.0$ or $1.5 \mathrm{~g}$ naringin per $\mathrm{kg}$ (dry matter basis), respectively. The basal diet (Table 1) was formulated to meet the NRC (2012) requirements for finishing pigs.

Table 1 Composition and analysis of the basal diet to test effects of naringin supplementation of finishing pigs

\begin{tabular}{|c|c|}
\hline Items & Diet \\
\hline \multicolumn{2}{|l|}{ Ingredients (\%) } \\
\hline Corn & 72.97 \\
\hline Soybean meal & 10.60 \\
\hline Wheat bran & 14.50 \\
\hline Limestone & 0.30 \\
\hline Calcium hydrogen phosphate & 0.20 \\
\hline $\mathrm{NaCl}$ & 0.30 \\
\hline Lysine & 0.13 \\
\hline Premix $^{1}$ & 1.00 \\
\hline Total & 100.00 \\
\hline \multicolumn{2}{|l|}{ Nutrient levels } \\
\hline Net energy $(\mathrm{MJ} / \mathrm{kg})$ & 13.28 \\
\hline Crude protein (\%) & 13.03 \\
\hline Calcium (\%) & 0.51 \\
\hline Total phosphorus (\%) & 0.43 \\
\hline Available phosphorus (\%) & 0.18 \\
\hline Lysine (\%) & 0.56 \\
\hline Methionine (\%) & 0.18 \\
\hline Threonine (\%) & 0.34 \\
\hline Tryptophan (\%) & 0.11 \\
\hline
\end{tabular}

${ }^{1}$ Provided per kilogram of diet: Copper: $\left(\mathrm{CuSO}_{4} \cdot 5 \mathrm{H}_{2} \mathrm{O}\right) 15 \mathrm{mg}$, Iron: $\left(\mathrm{FeSO}_{4} \cdot 7 \mathrm{H}_{2} \mathrm{O}\right) 100 \mathrm{mg}$, Zinc: $\left(\mathrm{ZnSO}_{4} \cdot 7 \mathrm{H}_{2} \mathrm{O}\right) 100 \mathrm{mg}$, Manganese: $\left(\mathrm{MnSO}_{4} \cdot \mathrm{H}_{2} \mathrm{O}\right) 40 \mathrm{mg}$, Selenium: $\left(\mathrm{Na}_{2} \mathrm{SeO}_{3}\right) 0.3 \mathrm{mg}$, lodine: $(\mathrm{KI}) 0.3 \mathrm{mg}$, vitamin A: $1750 \mathrm{IU}$, vitamin $\mathrm{D}_{3}: 200$ $\mathrm{IU}$, vitamin $\mathrm{E}: 11 \mathrm{IU}$, vitamin $\mathrm{K}_{3}: 0.5 \mathrm{mg}$, niacin: $20 \mathrm{mg}$, pantothenic acid :9 mg, folic acid: $0.3 \mathrm{mg}$, vitamin $\mathrm{B}_{1}: 1 \mathrm{mg}$, vitamin $B_{2}: 3 \mathrm{mg}$, vitamin $\mathrm{B}_{6}: 1.5 \mathrm{mg}$, vitamin $\mathrm{B}_{12}: 15 \mu \mathrm{g}$, biotin: $0.05 \mathrm{mg}$, choline chloride: $1.0 \mathrm{~g}$, phytase: $0.1 \mathrm{~g}$, antimold: $0.5 \mathrm{~g}$. 
All pigs were housed in pens $(2.6 \mathrm{~m} \times 4.2 \mathrm{~m})$ with solid concrete floors in an environmentally controlled room, and males were castrated. During the experiment, pigs had ad libitum access to feed and water. Feed intake was measured weekly, and the initial and final body weight of pigs in each pen was recorded to calculate the average daily gain (ADG), average daily feed intake (ADFI) and feed to gain ratio (F/G). After 50 days, the pig closest to the average weight of each replicate (six pigs/treatment, half males and half females) was selected and blood samples were collected from the jugular vein using a sterile syringe. The blood samples were centrifuged at $2000 \times g$ for 10 min to obtain the serum. The glucose (GLU), total protein (TP), albumin (ALB), globulin (GOB), high-density lipoprotein cholesterol (HDL-C), low-density lipoprotein cholesterol (LDL-C), total cholesterol (TC) and triglyceride (TG) concentrations and alanine aminotransferase (ALT) and aspartate aminotransferase (AST) activities in the serum were measured using an automatic biochemical analyzer 7020 (Hitachi, Tokyo, Japan). Feed was withdrawn from the pigs for $16 \mathrm{~h}$ prior to slaughter via exsanguination after electrical stunning. The warm carcass weight was recorded for calculation of carcass yield. The left side of the carcass was used to measure the carcass straight length, lean meat content, loin eye muscle area and backfat thickness (at the 4th-5th thoracic vertebra). Weights of the heart, liver and kidneys were also recorded.

The longissimus dorsi (LD) muscle from the 10th to 13th ribs of the left carcass was used for meat quality measurements. The values of $\mathrm{pH}_{45 \mathrm{~min}}$ and $\mathrm{pH}_{24 \mathrm{~h}}$ of $\mathrm{LD}$ were measured by portable $\mathrm{pH}$ meter $(\mathrm{pH}$ STAR, MATTHAUS, Germany). Objective color measurements (CIELAB system based on L* $=$ lightness, $a^{*}$ $=$ redness and $\mathrm{b}^{*}=$ yellowness) were performed at $24 \mathrm{~h}$ postmortem by using a CS-200 colorimeter (CHN spec, Hangzhou, China). The $L^{*}$ value ranged from 0 (black) to 100 (white), $a^{*}$ value component from green $(-)$ to red $(+)$, and $b^{*}$ value component from blue $(-)$ to yellow $(+)$. As suggested by the National Pork Producers Council (1991) and Honikel (1998), subjective LD muscle color $(1=$ pale pinkish gray to $6=$ dark purplish red) and marbling ( $1=$ devoid to $5=$ abundant) were scored via color card or marbling plate, respectively. Each sample was measured three times at different locations to calculate the average value. Intramuscular fat (IMF) and inosine monophosphate concentrations (IMP) of LD samples were analyzed using the Association of Analytical Chemists method and high performance liquid chromatography, respectively (Li et al., 2015; Prevolnik et al., 2005). A slice of fresh LD $(50.1 \pm 1.5 \mathrm{~g})$ was placed in a plastic container on a grid, parallel to the fiber direction, and the drip loss percentages were calculated after $24 \mathrm{~h}$ of storage at $4{ }^{\circ} \mathrm{C}$.

Total RNA was extracted from LD samples using a Trizol reagent (Takara, Dalian, China). The total RNA was treated with DNase I to remove DNA and synthesized as single-stranded CDNA using the PrimeScript ${ }^{\mathrm{TM}}$ RT reagent Kit (Code No.: RR047A, TaKaRa, Dalian, China), according to the manufacturer's protocol. mRNA expression was then assessed using the SYBR ${ }^{\circledR}$ Premix Ex Taq ${ }^{\mathrm{TM}}$ II kit (Code No.: RR820A, TaKaRa, Dalian, China), following the manufacturer's instructions. The reactions were run in triplicate with a QuantStudio ${ }^{T M} 6$ Flex RT-PCR system (Life Technologies, CA, USA), and the data were analyzed using the $2^{-\triangle \triangle^{C T}}$ method. The mRNA expression levels of four myosin heavy chain ( $M y H C$ ) isoform genes were determined. GAPDH was used as the endogenous control gene. All the primers are listed in Table 2.

Table 2 Primers used for quantitative real-time polymerase chain reaction to detect differences in gene expression levels

\begin{tabular}{|c|c|}
\hline Gene & Primer sequence $\left(5^{\prime}-3^{\prime}\right)$ \\
\hline $\mathrm{MyHCI}$ & $\begin{array}{l}\text { F: AAGGGCTTGAACGAGGAGTAGA } \\
\text { R: TTATTCTGCTTCCTCCAAAGGG }\end{array}$ \\
\hline \multirow[t]{2}{*}{ MyHC Ila } & F: GCTGAGCGAGCTGAAATCC \\
\hline & R: ACTGAGACACCAGAGCTTCT \\
\hline \multirow{2}{*}{ MyHC IIb } & F: ATGAAGAGGAACCACATTA \\
\hline & R: TTATTGCCTCAGTAGCTTG \\
\hline \multirow{2}{*}{ MyHC IIx } & F: AGAAGATCAACTGAGTGAACT \\
\hline & R: AGAGCTGAGAAACTAACGTG \\
\hline \multirow{2}{*}{ GAPDH } & F: GAAGGTCGGAGTGAACGGAT \\
\hline & R: CATGGGTAGAATCATACTGGAACA \\
\hline
\end{tabular}


Approximately $0.1 \mathrm{~g}$ tissue samples were weighed and homogenized in $1 \mathrm{~mL}$ of $0.9 \%$ saline on ice and centrifuged at $2000 \times \mathrm{g}$ for $10 \mathrm{~min}$ at $4^{\circ} \mathrm{C}$. Total protein content was then measured in the supernatant using the bicinchoninic acid method (Osnes et al., 1993). T-AOC (Code No.: A015-2), SOD (Code No.: A001-3), GPx (Code No.: A005) and catalase (CAT) (Code No.: A007-1-1) activities and MDA content (Code No.: A003-1) were measured at appropriate dilutions, according to corresponding procedures. All kits were purchased from Nanjing Jiancheng Bioengineering Institute (Nanjing, Jiangsu, China).

The Kolmogorov-Smirnov test was used to assess goodness-of-fit of data to normal distribution and ANOVA was used to analyze data differences between treatment groups using SPSS software (version 18.0, SPSS Inc., Chicago Illinois, USA). The results are presented as means and standard error of means (SE). Differences among treatment means were detected by Tukey's test; $P<0.05$ was considered significant, and $0.05<P<0.10$ was considered a tendency.

\section{Results}

The effects of dietary naringin supplementation on growth performance of finishing pigs are shown in Table 3. Naringin supplementation had no significant effect on these measures of growth $(P>0.05)$. However, compared with the control group, the ADG of the N1 group was increased numerically by $6.4 \%$ and $F / G$ ratio was decreased by $9.04 \%$.

Table 3 Effects of dietary naringin supplementation on growth, feed intake and efficiency of finishing pigs

\begin{tabular}{lrrrrrr}
\hline \multirow{2}{*}{ Trait $^{2}$} & \multicolumn{4}{c}{ Treatment $^{1}$} & SE & P-value \\
\cline { 2 - 4 } & \multicolumn{1}{c}{ N0 } & \multicolumn{1}{c}{ N1 } & N2 & N3 & & \\
\hline Initial body weight (kg) & 66.20 & 66.20 & 66.18 & 66.19 & 0.63 & 1.000 \\
Final body weight (kg) & 105.41 & 107.90 & 105.74 & 104.49 & 0.85 & 0.542 \\
ADG (kg/day) & 0.78 & 0.83 & 0.79 & 0.77 & 0.01 & 0.150 \\
ADFI (kg/day) & 2.59 & 2.51 & 2.50 & 2.61 & 0.03 & 0.360 \\
F/G & 3.32 & 3.02 & 3.16 & 3.39 & 0.67 & 0.181 \\
\hline
\end{tabular}

N0: no additive, N1, N2 and N3: 0.5, 1.0 and $1.5 \mathrm{~g}$ naringin per kg feed, respectively

${ }^{2}$ ADG: average daily gain, ADFI: average daily feed intake, F/G: feed to gain ratio

Effects of dietary naringin supplementation on serum profiles of finishing pigs are shown in Table 4. There were no significant differences in serum biochemical indices between control and naringin groups, apart from TG levels. Pigs in the N1 group had lower TG levels compared with the N0 group $(P<0.05)$.

Effects of dietary naringin supplementation on carcass traits of finishing pigs are shown in Table 5 . Loin eye muscle area was higher in pigs in the N1 and N2 groups compared with controls and lean meat content was higher in pigs in the N1 group compared with controls $(P<0.05)$. However, the other carcass traits, including warm carcass weight, carcass yield, carcass straight length, backfat thickness and tissue weight were not affected by the naringin supplementation treatments $(P>0.05)$. 
Table 4 Effects of dietary naringin supplementation on serum profiles of finishing pigs

\begin{tabular}{|c|c|c|c|c|c|c|}
\hline \multirow{2}{*}{ Items $^{2}$} & \multicolumn{4}{|c|}{ Group $^{1}$} & \multirow{2}{*}{ SE } & \multirow{2}{*}{$P$-value } \\
\hline & NO & N1 & N2 & N3 & & \\
\hline GLU (mmol/L) & 5.22 & 4.18 & 4.81 & 5.43 & 0.37 & 0.703 \\
\hline TP (g/L) & 67.65 & 67.30 & 68.15 & 67.03 & 0.41 & 0.820 \\
\hline ALB (g/L) & 41.03 & 42.23 & 42.58 & 40.58 & 0.33 & 0.078 \\
\hline GLB (g/L) & 26.63 & 25.08 & 25.58 & 26.45 & 0.42 & 0.566 \\
\hline ALB/GLB & 1.53 & 1.70 & 1.65 & 1.53 & 0.04 & 0.222 \\
\hline HDL-C (mmol/L) & 1.37 & 1.33 & 1.28 & 1.33 & 0.04 & 0.927 \\
\hline LDL-C (mmol/L) & 1.02 & 1.34 & 1.15 & 1.08 & 0.07 & 0.362 \\
\hline $\mathrm{TC}(\mathrm{mmol} / \mathrm{L})$ & 2.55 & 2.78 & 2.57 & 2.56 & 0.10 & 0.844 \\
\hline TG (mmol/L) & $0.36^{a}$ & $0.21^{\mathrm{b}}$ & $0.30^{\mathrm{ab}}$ & $0.34^{\mathrm{ab}}$ & 0.02 & 0.044 \\
\hline ALT (U/L) & 43.00 & 49.25 & 45.50 & 45.00 & 1.15 & 0.298 \\
\hline AST (U/L) & 29.25 & 22.25 & 30.25 & 24.75 & 1.49 & 0.183 \\
\hline
\end{tabular}

${ }^{1}$ N0: no additive, N1, N2 and N3: 0.5, 1.0 and $1.5 \mathrm{~g}$ naringin per $\mathrm{kg}$ feed, respectively

${ }^{2}$ ALT: alanine aminotransferase, AST: aspartate aminotransferase, TP: total protein, ALB: albumin, GLB: Globulin, GLU: glucose, HDL-C: high-density lipoprotein cholesterol, LDL-C: low-density lipoprotein cholesterol, TC: total cholesterol, TG: triglyceride

${ }^{a, b}$ Means with different superscripts in the same row differ significantly $(P<0.05)$

Table 5 Effect of dietary naringin supplementation on carcass traits of finishing pigs

\begin{tabular}{|c|c|c|c|c|c|c|}
\hline \multirow{2}{*}{ Items } & \multicolumn{4}{|c|}{ Group $^{1}$} & \multirow{2}{*}{ SE } & \multirow{2}{*}{$P$-value } \\
\hline & No & N1 & N2 & N3 & & \\
\hline Warm carcass weight $(\mathrm{kg})$ & 80.10 & 78.50 & 79.83 & 79.73 & 0.55 & 0.777 \\
\hline Carcass yield (\%) & 75.24 & 74.04 & 75.10 & 75.42 & 0.27 & 0.264 \\
\hline Carcass straight length (cm) & 96.10 & 96.38 & 97.63 & 97.75 & 0.78 & 0.859 \\
\hline Backfat thickness $(\mathrm{cm})$ & 5.04 & 4.80 & 5.06 & 5.17 & 0.12 & 0.797 \\
\hline Lean meat content (\%) & $46.39^{b}$ & $49.93^{\mathrm{a}}$ & $48.18^{\mathrm{ab}}$ & $47.89^{b}$ & 0.19 & 0.012 \\
\hline Loin eye area $\left(\mathrm{cm}^{2}\right)$ & $27.87^{\mathrm{b}}$ & $33.85^{\mathrm{a}}$ & $31.85^{\mathrm{a}}$ & $30.35^{\mathrm{ab}}$ & 0.79 & 0.030 \\
\hline Heart weight (g) & 343.38 & 366.55 & 349.70 & 361.33 & 7.60 & 0.735 \\
\hline Liver weight $(\mathrm{g})$ & 1538.85 & 1633.60 & 1701.83 & 1516.50 & 66.53 & 0.780 \\
\hline Kidneys weight (g) & 258.75 & 296.25 & 290.00 & 252.93 & 9.98 & 0.334 \\
\hline
\end{tabular}

${ }^{1} \mathrm{~N} 0:$ no additive, N1, N2 and N3: 0.5, 1.0 and $1.5 \mathrm{~g}$ naringin per $\mathrm{kg}$ feed, respectively

${ }^{\mathrm{a}, \mathrm{b}}$ Means with different superscripts in the same row differ significantly $(P<0.05)$

Table 6 summarizes the effects of naringin dietary supplementation on quality of meat from the LD. The $\mathrm{pH}_{45 \mathrm{~min}}$ and IMP content were higher in the N3 group compared with the N0 group $(P<0.05)$. In contrast, meat quality parameters such as $\mathrm{pH}_{24 \mathrm{~h}}$, incarnadine score (subjective color score), color indices $\left(\mathrm{L}^{*}, \mathrm{a}^{*}, \mathrm{~b}^{*}\right)$, drip loss, marbling score and IMF content were not significantly affected by the dietary treatment $(P>0.05)$.

Table 7 shows that dietary naringin did not affect the mRNA expression levels of $M y H C I$ and $M y H C$ IIx. There was a significant decrease in the level of MyHC IIb in the N3 group, and the MyHC IIa mRNA expression level was also significantly up-regulated $(P<0.05)$ in all three groups receiving naringin dietary supplementation. 
Table 6 Effect of dietary naringin supplementation on meat quality of finishing pigs

\begin{tabular}{|c|c|c|c|c|c|c|}
\hline \multirow{2}{*}{ Items $^{2}$} & \multicolumn{4}{|c|}{ Group $^{1}$} & \multirow{2}{*}{ SE } & \multirow{2}{*}{$P$-value } \\
\hline & NO & N1 & N2 & N3 & & \\
\hline $\mathrm{pH}_{45 \min }$ & $5.91^{b}$ & $5.93^{b}$ & $6.07^{b}$ & $6.60^{\mathrm{a}}$ & 0.10 & 0.035 \\
\hline $\mathrm{pH}_{24 \mathrm{~h}}$ & 5.41 & 5.40 & 5.43 & 5.43 & 0.01 & 0.476 \\
\hline Incarnadine score & 3.13 & 3.38 & 3.75 & 3.63 & 0.11 & 0.163 \\
\hline \multicolumn{7}{|l|}{ Colour indices } \\
\hline L* (lightness) & 42.28 & 41.06 & 38.42 & 37.98 & 1.46 & 0.725 \\
\hline a* (redness) & 4.33 & 5.36 & 4.22 & 4.29 & 0.43 & 0.251 \\
\hline b* (yellowness) & 2.98 & 2.65 & 2.05 & 2.07 & 0.33 & 0.733 \\
\hline Marbling score & 2.13 & 2.25 & 2.25 & 2.25 & 0.23 & 0.894 \\
\hline IMF (\%) & 2.52 & 2.79 & 2.71 & 2.77 & 0.20 & 0.973 \\
\hline IMP (\%) & $2.61^{\mathrm{a}}$ & $2.58^{\mathrm{a}}$ & $2.58^{\mathrm{a}}$ & $2.84^{b}$ & 0.04 & 0.026 \\
\hline Drip loss (\%) & 2.30 & 2.16 & 2.18 & 1.96 & 0.09 & 0.533 \\
\hline
\end{tabular}

Table 7 Effect of dietary naringin supplementation on relative mRNA expression levels of MyHC genes in muscle of finishing pigs

\begin{tabular}{|c|c|c|c|c|c|c|}
\hline \multirow{2}{*}{ Genes } & \multicolumn{4}{|c|}{ Group $^{1}$} & \multirow{2}{*}{ SE } & \multirow{2}{*}{$P$-value } \\
\hline & NO & N1 & N2 & N3 & & \\
\hline MyHC I & 1 & 1.12 & 1.11 & 1.15 & 0.03 & 0.323 \\
\hline MyHC IIa & $1^{b}$ & $1.36^{\mathrm{a}}$ & $1.25^{\mathrm{a}}$ & $1.26^{\mathrm{a}}$ & 0.05 & 0.002 \\
\hline МyHC IIb & $1^{a}$ & $0.87^{\mathrm{a}}$ & $0.90^{\mathrm{a}}$ & $0.80^{b}$ & 0.03 & 0.048 \\
\hline MyHC IIx & 1 & 0.89 & 0.88 & 0.85 & 0.04 & 0.618 \\
\hline
\end{tabular}

\footnotetext{
${ }^{1}$ N0: no additive, N1, N2 and N3: 0.5, 1.0 and $1.5 \mathrm{~g}$ naringin per $\mathrm{kg}$ feed, respectively

a,b Means with different superscripts in the same row differ significantly $(P<0.05)$

Dietary naringin supplementation did not affect activity of GPx and CAT $(P>0.05)$ or MDA content, but did increase the SOD activity $(P<0.05)$ in meat. Furthermore, T-AOC activity was higher in the N3 group than in the other three groups $(P<0.05)$. SOD and GPx activity in the liver was higher in groups that received dietary supplementation with $1.0 \mathrm{~g} / \mathrm{kg}$ and $1.5 \mathrm{~g} / \mathrm{kg}$ naringin compared with controls $(P<0.05)$. However, T-AOC and CAT activities and MDA content were not significantly different between control and naringin groups $(P>0.05)$. However, dietary naringin supplementation tended to increase the T-AOC activity $(P=$ $0.074)$ and reduce MDA content $(P=0.087)$ in liver tissue (Table 8).
} 
Table 8 Effect of dietary naringin supplementation on antioxidative enzyme activities and malondialdehyde content of meat and liver in finishing pigs

\begin{tabular}{|c|c|c|c|c|c|c|}
\hline \multirow{2}{*}{ Items $^{2}$} & \multicolumn{4}{|c|}{ Group $^{1}$} & \multirow{2}{*}{ SE } & \multirow{2}{*}{$P$-value } \\
\hline & No & N1 & N2 & N3 & & \\
\hline \multicolumn{7}{|l|}{ Meat } \\
\hline $\mathrm{T}-\mathrm{AOC}(\mu \mathrm{mol} / \mathrm{g})$ & $14.80^{\mathrm{b}}$ & $15.75^{\mathrm{b}}$ & $16.60^{b}$ & $19.38^{a}$ & 0.52 & 0.001 \\
\hline $\mathrm{SOD}(\mathrm{U} / \mathrm{mg})$ & $39.29^{b}$ & $47.59^{\mathrm{a}}$ & $48.37^{a}$ & $47.60^{\mathrm{a}}$ & 1.12 & 0.001 \\
\hline GPx (U/mg) & 3.58 & 3.51 & 3.58 & 3.15 & 0.20 & 0.870 \\
\hline CAT (U/mg) & 2.54 & 2.62 & 2.46 & 2.99 & 0.11 & 0.344 \\
\hline MDA (nmol/mg) & 0.24 & 0.18 & 0.16 & 0.18 & 0.02 & 0.646 \\
\hline \multicolumn{7}{|l|}{ Liver } \\
\hline $\mathrm{T}-\mathrm{AOC}(\mu \mathrm{mol} / \mathrm{g})$ & 94.27 & 96.60 & 96.15 & 114.94 & 3.27 & 0.074 \\
\hline $\mathrm{SOD}(\mathrm{U} / \mathrm{mg})$ & $345.64^{b}$ & $381.67^{\mathrm{ab}}$ & $425.46^{a}$ & $431.31^{a}$ & 13.30 & 0.042 \\
\hline GPx (U/mg) & $3.89^{\mathrm{c}}$ & $3.45^{\mathrm{C}}$ & $6.95^{\mathrm{b}}$ & $9.48^{\mathrm{a}}$ & 0.79 & 0.001 \\
\hline САT (U/mg) & 72.13 & 70.02 & 71.98 & 73.06 & 1.98 & 0.970 \\
\hline MDA (nmol/mg) & 0.34 & 0.29 & 0.30 & 0.28 & 0.01 & 0.087 \\
\hline
\end{tabular}

\footnotetext{
${ }^{1} \mathrm{~N} 0$ : no additive, N1, N2 and N3: 0.5, 1.0 and $1.5 \mathrm{~g}$ naringin per $\mathrm{kg}$ feed, respectively

2 T-AOC: total antioxidative capacity, SOD: superoxide dismutase, GPx: glutathione peroxidase, CAT: catalase, MDA: malondialdehyde

${ }_{a, b, c}$ Means with different superscripts in the same row differ significantly $(P<0.05)$
}

\section{Discussion}

Naringin is a major flavanone derivate in citrus fruits, which has been found to be associated with beneficial effects on a range of metabolic processes in animals. The current study examined the effects of naringin on growth performance parameters, serum biochemical indices, carcass traits, meat quality, oxidative stability, and mRNA expression of MYHC genes in pigs.

No significant effect of dietary naringin supplementation on growth performance was found, which supports the results of previous studies done in lambs and broilers (Bodas et al., 2012; Goliomytis et al., 2015). The serum TG level was decreased in pigs treated with $0.5 \mathrm{~g} / \mathrm{kg}$ naringin, which is in agreement with the results of Bodas et al. in lambs (Bodas et al., 2011b). Furthermore, in the current study, the loin eye muscle area and lean meat content of pigs was significantly increased in pigs treated with $0.5 \mathrm{~g} / \mathrm{kg}$ naringin. These results suggest that the optimal dosage for improving the anti-obesity properties in finishing pigs is approximately $0.5 \mathrm{~g} / \mathrm{kg}$ naringin. In a previous study, naringin dietary supplementation tended to decrease fat pads in broilers $(P=0.087$ ) (Goliomytis et al., 2015). In a previous experiment done by our group (unpublished data), dietary supplementation with $0.5 \%$ naringin reduced the weight of the abdominal fat by $38.07 \%$ and reduced the rate of abdominal fat by $36.84 \%$ in mice $(P<0.05)$. In addition, naringin was found to suppress the proliferation and differentiation of adipocytes, in vitro (Guo et al., 2016; Liu et al., 2007). Thus, it can be speculated that dietary naringin might reduce fat deposition by regulating fat metabolism in animals.

Pigs fed the $1.5 \mathrm{~g} / \mathrm{kg}$ naringin supplemented diet had higher $\mathrm{pH}_{45 \mathrm{~min}}$ and IMP values in LD tissue and concurrently a numerical decrease of $14.8 \%$ in drip loss was observed. Rosenvold and Andersen (2003) concluded that drip loss is associated with the early postmortem $\mathrm{pH}$, implying that the lower drip loss in pigs fed the $1.5 \mathrm{~g} / \mathrm{kg}$ naringin diet was induced by higher $\mathrm{pH}_{45 \mathrm{~min}}$. As an important indicator of meat quality, the IMP content is directly related to meat taste (Terasaki et al., 1965; Wang et al., 2014). Data in the current study showed a significant increase in IMP content in the $1.5 \mathrm{~g} / \mathrm{kg}$ naringin group, however the other meat quality characteristics were not affected by the addition of naringin. Previous studies in broilers, lambs and rabbits found that naringin supplementation had limited influence on meat quality parameters (Goliomytis et al., 2015; Jeon et al., 2004), indicating that naringin might play distinct roles in different animals.

There are four muscle fiber types in adult pig muscle, including slow-oxidative type I, fast oxidoglycolytic type IIA, and fast glycolytic types IIB and IIX, which are expressed by MyHC I, MyHC IIa, MyHC IIX, and $M y H C ~ I I b$, respectively (Zhang et al., 2015). Muscle fiber type composition is strongly related to meat quality (Zhang et al., 2019). For example, Ryu and Kim (2005) reported that the percentage of type IIB fibre 
is negatively correlated with $\mathrm{pH}_{45 \mathrm{~min}}$, but positively correlated with drip loss and lightness in pork. Muscles with a lower proportion of $\mathrm{MyHC} I$ and $\mathrm{MyHC}$ Ila had higher lightness and lower water-holding capacity, which negatively affected meat quality (Kim et al., 2013). In the current study, naringin treatments significantly up-regulated the MyHC Ila mRNA expression, which the MyHC Ilb mRNA level was obviously decreased by treatment with $1.5 \mathrm{~g} / \mathrm{kg}$ naringin, suggested that dietary naringin improves the meat quality by changing the muscle fiber type composition in pigs.

Naringin exhibits high antioxidant potential in meat (Viswanatha et al., 2017). Both hydroxyl and superoxide radicals are scavenged by naringin, in vitro. Moreover, naringin significantly inhibited the xanthine oxidase activity, which is the physiologic source of superoxide anions in eukaryotic cells (CaviaSaiz et al., 2010; Katsumura Y, 2000). Naringin also shows strong antioxidant activity in different animals and/or different conditions, in vivo. In broilers, the MDA value of muscle tissue was significantly decreased by naringin (Goliomytis et al., 2015). Naringin supplementation also enhanced T-AOC capacity and SOD ability, and decreased serum MDA level in laying hens (Lien et al., 2008). In lambs, supplementation with naringin $(2.5 \mathrm{~g} / \mathrm{kg})$ significantly reduced MDA levels of plasma and meat MDA levels stored at $4^{\circ} \mathrm{C}$ for up to 8 days (Simitzis et al., 2019). Bodas et al. (2012) reported that the antioxidant status of liver was improved when lambs were fed diets supplemented with $1.5 \mathrm{~g} / \mathrm{kg}$ naringin, but the oxidative stability of the meat did not seem to be significantly affected. In rodents, naringin reversed metabolic complications by ameliorating oxidative stress in mice as indicated by improved GPx activity and decreased MDA levels (Adebiyi et al., 2015; Liu et al., 2016). Naringin also had a protective effect in diabetic animals via improving antioxidant enzymes such as SOD, CAT, and GPx in hyperglycemic rats (Ali \& El Kader, 2004; Punithavathi et al., 2008). In the current study, dietary naringin improved oxidative stability in pigs via increasing SOD and TAOC activity in meat, as well as SOD and GPx activities in the liver. SOD is an enzyme that converts superoxide radicals into hydrogen peroxide and oxygen (Thirach et al, 2007). Changes in SOD activity indicate that naringin supplementation can eliminate free radicals and improve antioxidative status in meat and liver. GPx is a crucial enzyme for reducing reactive oxygen species and maintaining oxygen balance (Xu et al, 2014). The higher GPx activity level in the N2 and N3 groups indicates that naringin improved the antioxidative capacity of pigs. Furthermore, feeding naringin tended to decrease MDA levels and increase the T-AOC capacity in liver, although not significantly $(P<0.10)$.

To the best of our knowledge, this study is the first that describes the application of naringin as a feed additive in the diet of finishing pigs. However, there were a few limitations in the current study that should be addressed in future research, including the number and size variability of animals in the treatment groups. The mechanism related to the decrease in TG and the increase in lean meat at an optimal dose of $0.5 \mathrm{~g} / \mathrm{kg}$ naringin treatment should also be further investigated.

\section{Conclusion}

Supplemental naringin could improve loin eye muscle area and lean meat content and decrease serum TG level in finishing pigs. Dietary naringin also improved some aspects of meat quality and antioxidant status of pigs. Thus, naringin could serve as an effective feed additive in the diets of pigs.

\section{Acknowledgements}

This research was supported by the National key R\&D program of China (No. 2018YFD0500600), the Fund of Chongqing Agricultural Development (Grant No. 17409) and the Agricultural Research Outstanding Talent Training Program of China (Grant No. 16202). We thank LetPub (www.letpub.com) for its linguistic assistance during the preparation of this manuscript.

\section{Authors' Contributions}

JXH and QW designed the study, JW and QW performed the experiment. XYQ and QS analysed the data. QW contributed to the writing of the manuscript. RLQ carried out critical reading of the manuscript. All the authors agreed with the final version to be submitted.

\section{Conflict of Interest Declaration}

The authors declare that there is no conflict of interest.

\section{References}

Asahina, Y. \& Inubuse, M., 1928. Über die Konstitution des Naringenins (II. Mitteilung über die Flavanon-Glucoside). Chemische Berichte 61, 1514. Doi.org/10.1002/cber.19280610810

Adebiyi, O.O., Adebiyi, O.A. \& Owira, P.M., 2015. Naringin reverses hepatocyte apoptosis and oxidative stress associated with HIV-1 nucleotide reverse transcriptase inhibitors-induced metabolic complications. Nutrients 7 , 10352-10368. http://doi.org/10.3390/nu7125540

Ahmad, S.R., Gokulakrishnan, P., Giriprasad, R. \& Yatoo, M.A., 2015. Fruit-based natural antioxidants in meat and meat products: A review. Crit. Rev. Food Sci. Nutr. 55, 1503-1513. http://doi.org/10.1080/10408398.2012.701674 
Alam, M.A., Subhan, N., Rahman, M.M., Uddin, S.J., Reza, H.M. \& Sarker, S.D., 2014. Effect of citrus flavonoids, naringin and naringenin, on metabolic syndrome and their mechanisms of action. Adv. Nutr. 5, 404-417. http://doi.org/10.3945/an.113.005603

Ali, M.M. \& El Kader, M.A., 2004. The Influence of naringin on the oxidative state of rats with streptozotocin-induced acute hyperglycaemia. Z. Naturforsch C. 59, 726-733. http://doi.org/10.1515/znc-2004-9-1018

Bharti, S., Rani, N., Krishnamurthy, B. \& Arya, D.S., 2014. Preclinical evidence for the pharmacological actions of naringin: A review. Planta Med. 80, 437-451. http://doi.org/10.1055/s-0034-1368351

Bodas, R., Prieto, N., Jordan, M.J., Lopez-Campos, O., Giraldez, F.J., Moran, L. \& Andres, S., 2012. The liver antioxidant status of fattening lambs is improved by naringin dietary supplementation at $0.15 \%$ rates but not meat quality. Animal 6, 863-870. http://doi.org/10.1017/S175173111100214X

Bodas, R., Prieto, N., Lopez-Campos, O., Giraldez, F.J. \& Andres, S., 2011b. Naringin and vitamin E influence the oxidative stability and lipid profile of plasma in lambs fed fish oil. Res. Vet. Sci. 91, 98-102. http://doi.org/ 10.1016/j.rvsc.2010.07.028

Boots, A.W., Haenen, G.R. \& Bast, A., 2008. Health effects of quercetin: From antioxidant to nutraceutical. Eur. J. Pharmacol. 585, 325-337. http://doi.org/10.1016/j.ejphar.2008.03.008

Burkina, V., Zlabek, V., Halsne, R., Ropstad, E. \& Zamaratskaia, G., 2016. In vitro effects of the citrus flavonoids diosmin, naringenin and naringin on the hepatic drug-metabolizing CYP3A enzyme in human, pig, mouse and fish. Biochem. Pharmacol. 110-111, 109-116. http://doi.org/ 10.1016/j.bcp.2016.04.011

Cavia-Saiz, M., Busto, M.D., Pilar-Izquierdo, M.C., Ortega, N., Perez-Mateos, M. \& Muniz, P., 2010. Antioxidant properties, radical scavenging activity and biomolecule protection capacity of flavonoid naringenin and its glycoside naringin: A comparative study. J. Sci. Food Agric. 90, 1238-1244. http://doi.org/10.1002/jsfa.3959

EFSA, 2011. Scientific opinion on the safety and efficacy of naringin when used as a sensory additive for all animal species. EFSA J. 9, 2416. http://doi.org/10.2903/j.efsa.2011.2416

Goliomytis, M., Kartsonas, N., Charismiadou, M.A., Symeon, G.K., Simitzis, P.E. \& Deligeorgis, S.G., 2015. The influence of naringin or hesperidin dietary supplementation on broiler meat quality and oxidative stability. PLoS One 10, e0141652. http://doi.org/10.1371/journal.pone.0141652

Gonzalez, E. \& Tejeda, J.F., 2007. Effects of dietary incorporation of different antioxidant extracts and free-range rearing on fatty acid composition and lipid oxidation of Iberian pig meat. Animal 1(7), 1060-1067. http://doi.org/10.1017/S1751731107000195

Goodarzi Boroojeni, F., Manner, K. \& Zentek, J., 2018. The impacts of Macleaya cordata extract and naringin inclusion in post-weaning piglet diets on performance, nutrient digestibility and intestinal histomorphology. Arch. Anim. Nutr. 72, 178-189. http://doi.org/10.1080/1745039X.2018.1459342

Guo, X., Liu, J., Cai, S., Wang, O. \& Ji, B., 2016. Synergistic interactions of apigenin, naringin, quercetin and emodin on inhibition of 3T3-L1 preadipocyte differentiation and pancreas lipase activity. Obes. Res. Clin. Pract. 10, 327-339. http://doi.org/10.1016/j.orcp.2015.08.004

Honikel, K.O., 1998. Reference methods for the assessment of physical characteristics of meat. Meat Sci. 49, $447-457$. http://doi.org/10.1016/S0309-1740(98)00034-5

Jeon, S.M., Park, Y.B. \& Choi, M.S., 2004. Antihypercholesterolemic property of naringin alters plasma and tissue lipids, cholesterol-regulating enzymes, fecal sterol and tissue morphology in rabbits. Clin. Nutr. 23, 1025-1034. http://doi.org/10.1016/j.clnu.2004.01.006

Jiang, J. \& Xiong, Y.L., 2016. Natural antioxidants as food and feed additives to promote health benefits and quality of meat products: A review. Meat Sci. 120, 107-117. http://doi.org/10.1016/j.meatsci.2016.04.005

Jiao, H. Y., Su, W.W., Li, P.B., Liao, Y., Zhou, Q., Zhu, N. \& He, L.L., 2015. Therapeutic effects of naringin in a guinea pig model of ovalbumin-induced cough-variant asthma. Pulm. Pharmacol. Ther. 33, 59-65. http://doi.org/10.1016/j.pupt.2015.07.002

Kamboh, A.A. \& Zhu, W.Y., 2013. Individual and combined effects of genistein and hesperidin supplementation on meat quality in meat-type broiler chickens. J. Sci. Food Agric. 93, 3362-3367. http://doi.org/10.1002/jsfa.6185

Katsumura, Y.M.Y. \& Hata K., 2000. Bioflavonoids as antiradicals, antioxidants and DNA cleavage protectors. Cell Biol. Toxicol. 16, 91-98. http://doi.org/10.1023/A:1007685909018

Kim, G.D., Jeong, J.Y., Jung, E.Y., Yang, H.S., Lim, H.T. \& Joo, S.T., 2013. The influence of fiber size distribution of type IIB on carcass traits and meat quality in pigs. Meat Sci. 94, 267-273. http://doi.org/10.1016/j.meatsci.2013.02.001

Li, X.L., He, L.P., Yang, Y., Liu, F.J., Cao, Y. \& Zuo, J.J., 2015. Effects of extracellular polysaccharides of Ganoderma lucidum supplementation on the growth performance, blood profile, and meat quality in finisher pigs. Livestock Sci. 178, 187-194. http://doi.org/10.1016/j.livsci.2015.04.001

Lien, T.F., Yeh, H.S. \& Su, W.T., 2008. Effect of adding extracted hesperetin, naringenin and pectin on egg cholesterol, serum traits and antioxidant activity in laying hens. Arch. Anim. Nutr. 62, 33-43.

Liu, K., Wu, L., Shi, X. \& Wu, F., 2016. Protective effect of naringin against ankylosing spondylitis via ossification, inflammation and oxidative stress in mice. Exp. Ther. Med. 12, 1153-1158. http://doi.org/10.3892/etm.2016.3410

Liu, X.Y., Zhou, L., Liang, R.Y., Cao, L.Y. \& Wang, P.X., 2007. Effect of naringin on proliferation and differentiation of 3T3-L1 preadipocyte. Traditional Chinese Drug Res. and Clin. Pharm. 18, 176-179. (In Mandarin) http://doi.org/10.3321/j.issn:1003-9783.2007.03.002

Liu, Y., Wang, Z.S. \& Zhou, A.G., 2009. Effects of hesperidin and chlorogenic acid on performance, antioxidance and immunity of weaned piglets. Chin. J. Vet. Sci. 29, 1233-1236.

National Pork Producers Council, 1991. Procedures to evaluate market hogs. 3rd edition. National Pork Producers Council publication, Des Moines, IA.

NRC, 2012. Nutrient requirements of swine. Eleventh revised edition. National Academies Press, Washington DC, 
Osnes, T., Sandstad, O., Skar, V., Osnes, M. \& Kierulf, P., 1993. Total protein in common duct bile measured by acetonitrile precipitation and a micro bicinchoninic acid (BCA) method. Scand. J. Clin. Lab. Invest. 53, 757-763. http://doi.org/10.3109/00365519309092582

Prevolnik, M., ČandekPotokar, M., Škorjanc, D., Velikonja-Bolta, Š., Škrlep, M., Žnidaršiča, T. \& Babnik, D., 2005. Predicting intramuscular fat content in pork and beef by near infrared spectroscopy. J. Near Infrared Spectroscopy 13, 77-85. http://doi.org/10.1255/jnirs.460

Punithavathi, V.R., Anuthama, R. \& Prince, P.S., 2008. Combined treatment with naringin and vitamin C ameliorates streptozotocin-induced diabetes in male Wistar rats. J. Appl. Toxicol. 28, 806-813. http://doi.org/10.1002/jat.1343

Rosenvold, K. \& Andersen, H.J., 2003. Factors of significance for pork quality - a review. Meat Sci. 64, $219-237$. http://doi.org/10.1016/s0309-1740(02)00186-9

Ryu, Y.C. \& Kim, B.C., 2005. The relationship between muscle fiber characteristics, post-mortem metabolic rate, and meat quality of pig longissimus dorsi muscle. Meat Sci. 71, 351-357. http://doi.org/10.1016/j.meatsci.2005.04.015

Salami, S.A., Guinguina, A., Agboola, J.O., Omede, A.A., Agbonlahor, E.M. \& Tayyab, U., 2016. Review: In vivo and postmortem effects of feed antioxidants in livestock: a review of the implications on authorization of antioxidant feed additives. Animal 10, 1375-1390. http://doi.org/10.1017/S1751731115002967

Simitzis, P.E., Charismiadou, M.A., Goliomytis, M., Charalambous, A., Ntetska, I., Giamouri, E. \& Deligeorgis, S.G., 2019. Antioxidant status, meat oxidative stability and quality characteristics of lambs fed with hesperidin, naringin or alpha-tocopheryl acetate supplemented diets. J. Sci. Food Agric. 99, 343-349. http://doi.org/10.1002/jsfa.9193

Terasaki, M., Kajikawa, M., Fujita, E. \& Ishii, K., 1965. Studies on the flavor of meats. Part I. Formation and degradation of inosinic acids in meats. Agric. Biol. Chem. 29, 208-215. http://doi.org/10.1080/00021369.1965.10858377

Thirach, S., Cooper, C.R., Vanittanakom, P. \& Vanittanakom, N., 2007. The copper, zinc superoxide dismutase gene of penicillium marneffei: cloning, characterization, and differential expression during phase transition and macrophage infection. Medical Mycology 45, 409-417. http://doi.org/10.1080/13693780701381271

Viswanatha, G.L., Shylaja, H. \& Moolemath, Y., 2017. The beneficial role of naringin, a citrus bioflavonoid, against oxidative stress-induced neurobehavioral disorders and cognitive dysfunction in rodents: A systematic review and meta-analysis. Biomed. Pharmacother. 94, 909-929. http://doi.org/10.1016/j.biopha.2017.07.072

Wang, X.F., Liu, G.H., Cai, H.Y., Chang, W.H., Ma, J.S., Zheng, A.J. \& Zhang, S., 2014. Attempts to increase inosinic acid in broiler meat by using feed additives. Poult. Sci. 93, 2802-2808. http://doi.org/10.3382/ps.2013-03815

Xu, J., Xu, C., Chen, X., Cai, X., Yang, S., Sheng, Y. \& Wang, T., 2014. Regulation of an antioxidant blend on intestinal redox status and major microbiota in early weaned piglets. Nutr. 30, 584-589. http://doi.org/10.1016/j.nut.2013.10.018

Xu, X., Leng, J.Y., Gao, F., Zhao, Z., Deng, W., \& Liang, X., Zhang, Y., Zhang, Z., Li, M., Sha, A. \& Yang, Z., 2014. Differential expression and anti-oxidant function of glutathione peroxidase 3 in mouse uterus during decidualization. FEBS Letters 588, 1580-1589. http://doi.org/10.1016/j.febslet.2014.02.043

Zaidun, N.H., Thent, Z.C. \& Latiff, A.A., 2018. Combating oxidative stress disorders with citrus flavonoid: Naringenin. Life Sci. 208, 111-122. http://doi.org/10.1016/j.Ifs.2018.07.017

Zhang, C., Luo, J., Yu, B., Zheng, P., Huang, Z., Mao, X., He, J., Yu, J., Chen, J. \& Chen, D., 2015. Dietary resveratrol supplementation improves meat quality of finishing pigs through changing muscle fiber characteristics and antioxidative status. Meat Sci. 102, 15-21. http://doi.org/10.1016/j.meatsci.2014.11.014

Zhang, Y., Yu, B., Yu, J., Zheng, P., Huang, Z., Luo, Y., Luo, J., Mao, X., Yan, H., He, J. \& Chen, D., 2019. Butyrate promotes slow-twitch myofiber formation and mitochondrial biogenesis in finishing pigs via inducing specific microRNAs and PGC-1alpha expression1. J. Anim. Sci. 97(8), 3180-3192. http://doi.org/10.1093/jas/skz187 